\section{Experiments on the buckling behaviour of glass columns. part 2.}

KINGA NEHME - Assoc. Prof., University of Debrecen, Department of Civil Engineering * kpankhardt@yahoo.com

ANDRÁs JAKAB - civil engineer, Üveg-Fémszer Kft. - jakabandreas@gmail.com

Salem Georges NEHME - Assoc. Prof., BME, Department of Construction Materials and Engineering Geology - sgnehme@yahoo.com

Érkezett: 2013. 10. 16. - Received: 16. 10. 2013. - http://dx.doi.org/10.14382/epitoanyag-jsbcm.2013.21

\section{Abstract}

The authors demonstrated in a separate paper [1] the buckling behaviour of load-bearing glass columns and also the load bearing capacity issues of glass fins based on laboratory experiments. Present paper focuses on load-bearing glass columns and the stability issues of glass fins based on existing calculation methods of the critical load of glass columns. Authors compare the results of the laboratory experiments and theoretical calculations. The results are analysed with the calculation procedures in the focus of the international literature. The laboratory experiments were carried out at the BME, Department of Construction Materials and Engineering Geology. More than 60 specimens where loaded until fracture. Based on the experimental and theoretical results, the critical load was determined and the fracture and stability processes were illustrated by force-deflection diagrams. The critical load vs. slenderness responses were determined for fins consisted of monolithic (single layer glass) and laminated glass as well.

Keywords: glass column, buckling, load bearing glass, stability, transparency

\section{Introduction}

Heat-treatment procedure is the most often used glass strengthening method for building glasses. Two different types of so-called pre-stressed glass are produced with the heat strengthening method: tempered and heat strengthened glass. With lamination of several glass panes, multi-layered (hereinafter laminated) glass is produced. The interlayer material serves two purposes: (i) to keep glass splinters in place during the fracture process to reduce the risk of injury and (ii) to increase residual load bearing capacity $[2,3]$. Interlayer material used in laminated glass is EVA (ethyl-vinyl-acetate) foil.

The structural behaviour of laminated glass lies between two limits, the so-called lower (layered) limit, where the glass panes react without a shear bond and the upper (monolithic) limit, where all glass panes are rigidly connected. For both limits, stresses in the glass panes can be calculated using the known formulas and models. In reality, the maximum stress of the laminate lies between those two limits. Calculation methods and formulae for the buckling force should match these ultimate values.

The most known formula is Euler's formula to determine the critical load (hereinafter critical force) of a column. Question arises: Can be this formula applied for glass columns consisted of single layer glass and for laminated glass as well?

In the international literature four formulae for the buckling force of laminated glass columns exist. One of the formulae results in conservative values of the critical buckling force [4], one of them results correct values in the "lower" and "upper" limits of the critical buckling force [5], and one of them results in correct "lower" and conservative "upper" limit of the critical buckling force [6]. Three of the formulae $[4,5,6]$ do not contain a distinct parameter which controls the transition from the lower to the upper limit of the critical buckling force. One of the formulae [7] introduces a coupling parameter which
Kinga NEHME

MSc Civil Engineer, PhD, Associate Professor at the Department of Civil Engineering, University of Debrecen. Owner of Struktúra Ltd. engineering office (design, quality control). Member of the Technical committee of Glass Working Group (MSZT/MB 112) of Hungarian Standardization Institute; Hungarian Group of fib; Hungarian engineer chamber (MMK: 01-9160). Fields of interests: load bearing glasses, testing of construction materials, design, recycling of building materials.

András JAKAB

MSc Civil Engineer, designer at Üveg-FémSzer Ltd. Fields of interests: glass construction, glass columns, construction technology and management.

Salem G. NEHME MSc Civil Engineer, PhD, Associate Professor at the Department of Construction Materials and Engineering Geology, Budapest University of Technology and Economics (BME). Member of the Technical committee of Glass Working Group (MSZT/MB 112) of Hungarian Standardization Institute; Hungarian Group of fib; Hungarian engineer chamber (MMK: 01-9159). Fields of interests: concrete technology, mass concrete, self-compacting concrete, fibre reinforced concrete, quality control of building materials, non-destructive testing reinforced concrete structures, recycling of concrete.

controls the transition between the lower and the upper limit of buckling force of laminated glass columns.

Further question arises: Can be all these formulae applied for glass columns consisted of float glasses and for heatstrengthened glass as well?

\section{Experimental and theoretical studies}

\subsection{Influencing factors of buckling behaviour of glass columns}

To perform engineering calculations, the affecting factors on glass and interlayer material (e.g. effect of tempering should be studied) should be supplemented by laboratory testing.

Different influencing factors should be taken into account for the calculation of buckling behaviour and strength of a single or laminated glass pane. According to Wölfel's calculations [8], the primary interlayer property that influences the strength and deflection is the shear modulus, $G$, of the interlayer. In the case of thin or large size glass, where the deformations (deflections) are considerable, temperature dependent flexural stiffness $\left(D_{f}\right)$ of the overall laminate is more significant.

The following main influencing factors on the buckling behaviour of glass columns were experimentally studied:

- effect of thickness of glass pane,

- effect of number of glass layers,

- effect of heat-strengthening,

- effect of slenderness of critical force of glass column.

\subsection{Laboratory experiments}

\subsubsection{Test parameters}

Laboratory experiments were carried out to study the buckling behaviour of single and laminated glass columns at 
the Department of Construction Materials and Engineering Geology, BME. All glass specimens were loaded in compression by concentrated load by variable specimen heights and a constant nominal width of $80 \mathrm{~mm}$.

Single layer float glass, single layer heat-strengthened glass and laminated glass consisted of both float and heatstrengthened glass layers were tested. Although single layer glass and float glass are usually not used in load bearing glass columns, the effect of heat-strengthening on the buckling behaviour can be studied and can be compared with existing calculation methods in this way. The experimental procedure and test set-up is presented in [1].

Test parameters of glass specimens were the followings [1]:

Constants: test arrangement, the type of support; width of glass $(80 \mathrm{~mm})$; interlayer material (EVA foil with thickness of $0.38 \mathrm{~mm})$; edgework; temperature $\left(+23 \pm 5^{\circ} \mathrm{C}\right)$.

Variables: type of glass layers: HSG/ non heat-treated Float; height of specimens: $1000 \mathrm{~mm} ; 920 \mathrm{~mm} ; 840 \mathrm{~mm}$; number of glass layers and the thickness of specimens: single layer: $8 \mathrm{~mm}$; $12 \mathrm{~mm}$, laminated: $2 \times 4 \mathrm{~mm} ; 2 \times 6 \mathrm{~mm} ; 8+4 \mathrm{~mm}$, laminated: $3 \times 4 \mathrm{~mm}$; The rate of loading: $0,5 \mathrm{~mm} / \mathrm{min} ; 1 \mathrm{~mm} / \mathrm{min}$.

Support: Height of fixing: $95 \mathrm{~mm}$; rubber plate (Shore A 80) was used between the steel supports and the glass.

Simplified designation is used to distinguish the studied specimens; e.g. H_2(4.4)_2_920_0.5

- H, F: Type of glass: H - HSG; F - non heat-treated float glass;

- 2(4.4): Number of glass layers e.g.: $2 \times 4 \mathrm{~mm}$ laminated glass;

- 2: The number of specimen;

- 920: Nominate height of specimen $[\mathrm{mm}]$;

- 0.5 : Rate of loading $[\mathrm{mm} / \mathrm{min}]$.

\section{Calculation methods for buckling of glass columns}

\subsection{Critical force of glass columns consisted of single layer glass}

\subsubsection{Calculation of critical force with Euler's method}

The buckling behaviour of the single layer (monolithic) glass and that of laminated glass with rigidly bonded glass layers (upper limit) is similar to the buckling behaviour of an ideal elastic rod tested in compression. In this case the calculation of the critical buckling force can be determined with Euler's method. Euler's formula is the basis of the calculations for the critical buckling force of glass columns.

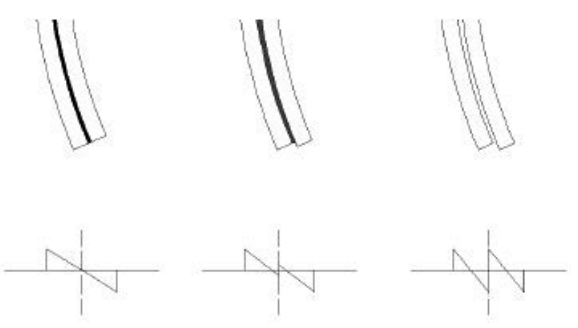

Fig. 1. a) monolithic behaviour, b) real behaviour; c) lower (layered) limit

1. ábra a) Monolitikusan együttdolgozó, b) Valós viselkedés c) Nem együttdolgozó rétegek

The critical buckling force of glass columns with Euler's formula can determined as follows (Eq. 1):
$N_{c r}=\frac{\pi^{2} \cdot E \cdot I}{L_{c r}^{2}}$

where:

$N_{c r}$ - critical force;

$L_{c r}$ - critical buckling length;

$E$ - Young's modulus of glass;

I - moment of inertia.

\subsection{Calculation of critical force of glass columns consisted of laminated glass}

Authors have compared the results of thelaboratory experiments and theoretical calculations. The results were analysed with the calculation procedures in the focus of the international literature. Simplified designation is used for the studied calculation methods of critical buckling force of laminated glass tested in compression, where in the designations in the lower indices mean:

$L$ - Single glass layers (without use of foil interlayer material);

$\mathrm{O}$ - Laminated glass, with non-bonded glass layers („lower

limit", with use of foil interlayer material);

$U$ - Laminated glass, with rigidly bonded glass layers („upper limit", with use of foil interlayer material);

$F$ - Foil interlayer material in laminated glass.

\subsubsection{Allen's method}

The calculation method of Allen [4] should be used only in the case of laminated glass with use of symmetrical glass layer thicknesses (laminated glass consisted of glass layers and interlayer material with similar thicknesses). In this formula the shear modulus of the interlayer foil material influences the critical buckling force of the glass column. The formula results in conservative values of the critical buckling force (Eq. 2).

$$
N_{c r}=\frac{N_{c r \cdot O}}{1+\frac{2 \cdot N_{c r \cdot O}}{\left[\frac{G_{f} \cdot b \cdot\left(v_{f}+v\right)^{2}}{v_{f}}\right]}}
$$

where:

$N_{c r . O}$ - critical buckling force of laminated glass "lower limit";

$G_{f}$ - shear modulus of the foil interlayer material;

$v_{f}$ - thickness of the foil interlayer material;

$v$ - thickness of the glass layer;

$b$ - width of the glass column.

\subsubsection{Method of Sattler et al.}

The formula by Sattler et al. (see Eq. 3) results correct values in the "lower" and "upper" limits of the critical buckling force and can be applied in the case of with non-symmetrical layered laminated glass as well.

$N_{c r}=\frac{\pi^{2} \cdot\left(1+\alpha+\pi^{2} \cdot \alpha \cdot \beta\right)}{1+\pi^{2} \cdot \beta} \cdot \frac{D_{O}}{L_{c r}^{2}}$

where:

$D_{O}$ - bending stiffness of laminated glass "lower limit";

$\alpha$ - coefficient depending on the moment of inertia;

$\beta-$ coefficient depending on the stiffness;

$L_{c r}$ - the critical buckling length. 


\subsubsection{Zenkert's method}

The formula by Zenkert (see Eq. 4) results in correct "lower" and conservative "upper" limit of the critical buckling force and can be applied in the case of with non-symmetrical layered laminated glass as well.

$N_{c r}=\frac{\frac{\pi^{4} \cdot D_{L} \cdot D_{O}}{D_{f} \cdot L_{c r}^{4}}+\frac{\pi^{2} \cdot D_{O}}{L_{c r}^{2}}}{1+\frac{\pi^{2} \cdot D_{O}}{D_{f} \cdot L_{c r}^{2}}}$

where:

$D_{L}$ - bending stiffness of single glass layers in laminated glass;

$D_{O}$ - bending stiffness of non-bonded glass layers;

$D_{f}$ - bending stiffness of foil;

$L_{c r}-$ the critical buckling length.

\subsubsection{Blaauwendraad's method}

The dimensionless $\xi$ parameter in (see Eq. 5) controls the contribution of the foil between the two glass layers.

$N_{c r}=(1-\xi) \cdot N_{c r . L}+\xi \cdot N_{c r . U}$

where:

$N_{c r}$ - critical buckling force (in the indices $L$ : the "lower

limit", $U$ : the "upper limit");

$\mathbf{x}$ - coupling parameter;

$f \quad$ - flexibility of the layers (in the indices 1, 2: glass layer

No. 1 and No. $2, f$ : foil interlayer material).

The coupling parameter (see Eq. 6) should be determined in the case of laminated glass consisted of two glass layers:

$\xi=\frac{f_{1}+f_{2}}{f_{1}+f_{f}+f_{2}}$

The modified coupling parameter (3.7) is in the case of laminated glass consisted of three glass layers:

$\xi=\frac{f_{1}+f_{2}+f_{3}}{f_{1}+f_{f}+f_{2}+f_{f}+f_{3}}$

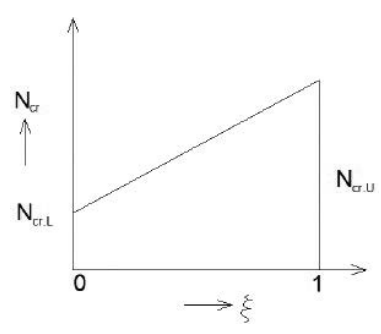

Fig. 2. Coupling parameter $(\xi)$

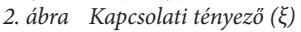

Fig. 2. indicates the possible range of the values of the coupling parameter, $\xi=0$ in the case of laminated glass consisted of non-bonded glass layers and $\xi=1$ in the case of monolithically bonded glass layers.

\section{Experimental and theoretical results}

\subsection{Influencing factors of buckling behaviour of glass columns}

\subsubsection{Effect of support type}

The supporting structures of glass columns are usually designed as fixed connections e.g. steel shoe [1], where damping material e.g. hard rubbers or plastics is placed between the surfaces of the glass and the steel plate, to avoid high stress concentrations in the contacting area. Due to different load histories (e.g. wind load) of a façade glazing, the glass fin deforms as well. During the load transfer of a glass fin to the supporting structure, deformations occur in the damping material, therefore the effect of the initial geometrical imperfections increase. In this paper the authors focus on structural elements without geometrical imperfections (study of geometrical imperfections is aim of future work). In the case of high compression of the damping material, or use of soft rubbers, as well as inappropriate finishing (e.g. rotation of the fin within the support) the initially designed fixed support behaves rather as a pinned connection. Fig. 3. indicates the importance of the type of the support, which influences the critical buckling force. The critical buckling force increases in the supporting structure in the case of reduced rotations of the glass fin.

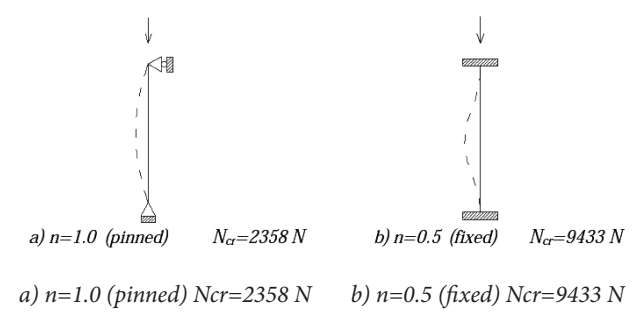

Fig. 3. Critical buckling force and schematic buckling shape of a float glass specimen with $1000 \mathrm{~mm}$ height and $8 \mathrm{~mm}$ thickness, in the case of a) pinned and $b$ ) fixed support

3. ábra $1000 \mathrm{~mm}$ magas $8 \mathrm{~mm}$ vastag float üveg próbatest kritikus ereje és sematikus kihajlási alakja, a) csuklós és b) befogott kapcsolat esetén

The deformations of the specimens were recorded with Olympus high speed camera. The deformed shapes of the specimens during the buckling behaviour were studied. Three different stages can be distinguished in the buckling behaviour of glass columns. In the $1^{\text {st }}$ Stage the elastic deformation of the damping material (rubber plates) influences the vertical and horizontal displacements and no buckling occur (first stable stage). The $2^{\text {nd }}$ Stage is a short term stage which indicates a geometrical instable condition (in which direction the buckling will occur) and the specimen loses its former stability (bound phenomenon, instability). The $1^{\text {st }}$ and $2^{\text {nd }}$ Stages are mainly influenced by the initial supporting conditions (e.g. quality of finishing work) and type of the fixing varies until the ultimate deformation of the damping material under loading conditions. Before the $3^{\text {rd }}$ Stage, visible inflexion points in the buckling shape can be distinguished, see Fig. 4.

The most dense fragmentation pattern can be observed in the fractured specimens in the region of the inflexion points. In the $3^{\text {rd }}$ Stage both the vertical and the horizontal displacements increase until fracture of glass (second stable stage). This Stage is less influenced by the initial supporting conditions. The continuous compression of the elastic damping material during loading leads to variable supporting conditions, therefore the coefficient of fixing $(n)$ changes during the test.

The coefficient of fixing $(n)$ should be determined to compare the results of laboratory experiments and those of the calculation methods. The coefficient of fixing $(n)$ was determined with use of the test results of single layer float glass. Coefficient of 
fixing $n=0.645$ was applied in the analytical study of different calculation methods of the critical buckling force $\left(N_{c c}\right)$.

Table 1. summarises the main physical properties of glass and interlayer material used in the calculations.

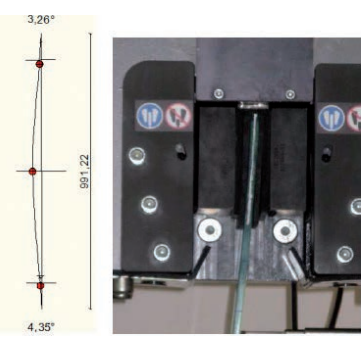

Fig. 4. Buckling shape in the region of the upper support ( $3^{\text {rd }}$ Stage)

4. ábra Kihajlási alak a felső megtámasztás környezetében (3. szakasz)

$\begin{array}{lccc}\text { Properties } & \text { Unit } & \text { Glass } & \text { EVA foil } \\ \text { Specific gravity } & \mathrm{g} / \mathrm{cm}^{3} & 2.5 & 0.95 \\ \text { Thickness } & \mathrm{mm} & \text { variable } & 0.38 \\ \text { Young's modulus at } \mathbf{2 3} \pm \mathbf{2}{ }^{\circ} \mathbf{C} & \mathrm{N} / \mathrm{mm}^{2} & 70000 & 1.2< \\ \text { Shear modulus at } \mathbf{2 3} \pm \mathbf{2}{ }^{\circ} \mathbf{C} & \mathrm{N} / \mathrm{mm}^{2} & 29200 & 4.54 \\ \text { Poisson ratio at } \mathbf{2 3} \pm \mathbf{2}{ }^{\circ} \mathbf{C} & - & 0.23 & 0.32\end{array}$

Table 1. Main physical properties of glass and EVA foil interlayer material [2]

1. táblázat Üveg és EVA fólia lamináló anyag föbb fizikai jellemzői [2]

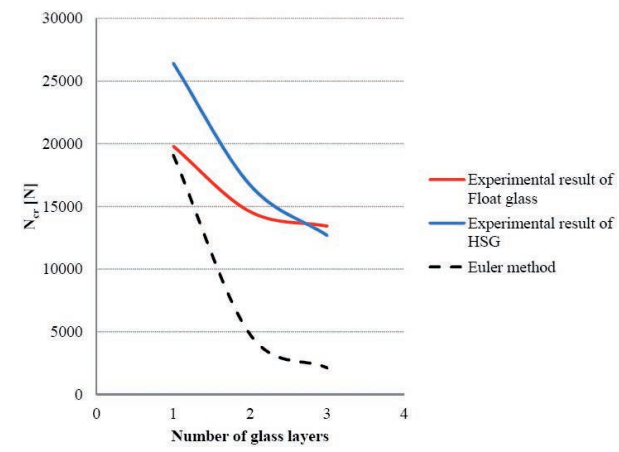

Fig. 5. Critical buckling force with Euler's formula in the case of single and laminated glass of 1000 height, consisted of float or HSG glass and that of tested glass vs. number of glass layers

5. ábra Euler-féle elmélettel számitott $1000 \mathrm{~mm}$ magas, float vagy HSG üvegből felépülö egy és többrétegü (nem együttdolgozó) üvegek valamint a kísérleti üvegek kritikus teher értékei, az üveg rétegszámának függvényében

\subsubsection{Calculation of critical force with Euler's formula}

The calculation method of the critical buckling force with Euler's formula does not distinguish between float and heatstrengthened (HSG) glass. Fig. 5. indicates the experimental results of single layer and laminated glass consisted of float or HSG glass layers with total thicknesses of $12 \mathrm{~mm}$ and also indicates the calculated values with Euler's formula. Based on the experimental and theoretical results, Euler's formula should be applied only in the case of float, monolithic single layer glass to determine the critical buckling force.

\subsubsection{Critical buckling force based on the experiments and theoretical formulae}

Table 2. summarises the calculated and experimental results of the critical buckling force. Although Euler's formula should be applied only in the case of single layer float glass, the authors suggest the values also for further types of tested glass specimens for observation purposes.

The critical buckling force with Sattler's formula overestimates the experimental values in the case of laminated glass consisted of float glass and gives correct values in the case of laminated glass consisted of HSG glass. The critical buckling force with Allen's and Zenkert's formulae result the same, usually lower, conservative values compared to the experimental results. The critical buckling force with the use of the Blaauwendraad's formula results the most conservative lowest values. In the case of the Blaauwendraad's formula both the "lower limit" and the "upper limit" can be determined (Fig. 6). Table 3. indicates the quantitative comparison of calculated and experimental results of the critical buckling force.

\subsubsection{Effect of heat-strengthening}

Euler's formula should not be applied in the case of HSG or laminated glass. All of the studied theoretical formulae result conservative values in the case of laminated glass consisted of HSG glass layers. The heat-strengthening increases the critical buckling force of glass columns. In the case of a single layer HSG glass with height of $1000 \mathrm{~mm}$ the critical buckling force increased with $\sim 30 \%$ compared to that of float glass.

\subsubsection{Effect of number of glass layers}

Based on the experimental results, the buckling force decreases with the increase of the number of glass layers in laminated glass. In Fig. 5. the number of the applied glass layers in laminated glass is indicated. The influence of the stiffness (and the effect of the shear modulus) of the interlayer material is increased in the case of laminated glass by the increase of the number of glass layers.

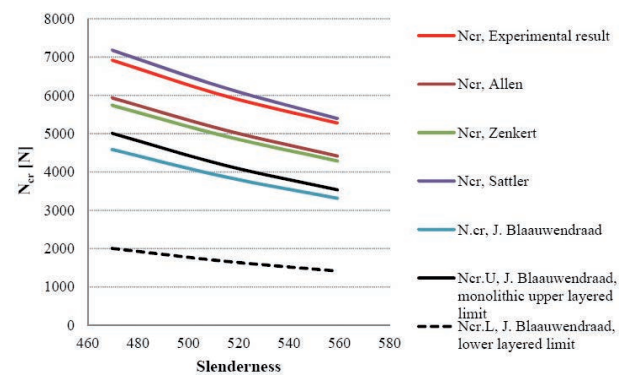

Fig. 6. Critical buckling force vs. slenderness of laminated glasses consisted of HSG 4.4 glass layers based on theoretical calculations and laboratory experimental results 6. ábra Laminált HSG 4.4 üvegek kritikus teher és karcsúság összefüggése, különbözö számitási eljárások és a laboratóriumi kísérleti eredmények alapján

\subsubsection{Effect of slenderness on critical force of glass column}

Based on the theoretical calculations and laboratory experimental results, Fig. 6. indicates the critical buckling force vs. slenderness of laminated glass consisted of two HSG glass layers with thickness of $2 \times 4 \mathrm{~mm}$. In the case of Blaauwendraad's formula both the "lower limit" and the "upper limit" were determined. Blaauwendraad's formula results correct values in the case of laminated glass consisted of float glass layers, but in the case of HSG glass a shift factor of the coupling parameter, $\xi$ should be introduced. In the case of conservative engineering calculations the use of Blaauwendraad's formula is suggested. 


\begin{tabular}{|c|c|c|c|c|c|c|c|c|}
\hline \multirow{2}{*}{$\begin{array}{l}\text { Height } \\
{[\mathrm{mm}]}\end{array}$} & \multirow{2}{*}{$\begin{array}{c}\text { Type } \\
\text { of glass }\end{array}$} & \multirow{2}{*}{$\begin{array}{l}\text { Number } \\
\text { of glass } \\
\text { layers }[\mathrm{mm}]\end{array}$} & \multicolumn{6}{|c|}{ Critical buckling force $\left(\mathbf{N}_{\mathrm{cr}}\right)[N]$} \\
\hline & & & $\begin{array}{l}\text { Experimental } \\
\text { results }\end{array}$ & Euler & $\begin{array}{l}\text { Allen } \\
{[4]}\end{array}$ & $\begin{array}{c}\text { Zenkert } \\
\text { [5] }\end{array}$ & $\begin{array}{c}\text { Sattler } \\
{[6]}\end{array}$ & $\begin{array}{c}\text { Blaauwendraad } \\
{[7]}\end{array}$ \\
\hline \multirow{11}{*}{1000} & \multirow{5}{*}{ Float } & $1(8)$ & 5672 & 5657 & - & - & - & - \\
\hline & & $1(12)$ & 19803 & 19091 & - & - & - & - \\
\hline & & $2(4.4)$ & 3490 & 1414 & 4428 & 4299 & 5409 & 3319 \\
\hline & & $2(6.6)$ & 14575 & 4773 & 12028 & 12224 & 16869 & 11562 \\
\hline & & $3(4.4 .4)$ & 13425 & 2121 & 13361 & 13844 & 15208 & 9471 \\
\hline & \multirow{6}{*}{ HSG } & 1(8) & 7506 & 5657 & - & - & - & - \\
\hline & & $1(12)$ & 26420 & 19091 & - & - & - & - \\
\hline & & $2(4.4)$ & 5278 & 1414 & 4417 & 4289 & 5397 & 3315 \\
\hline & & $2(6.6)$ & 16699 & 4773 & 13259 & 12835 & 16206 & 10524 \\
\hline & & $2(8.4)$ & 17495 & 6364 & 12028 & 12224 & 16869 & 11562 \\
\hline & & $3(4.4 .4)$ & 12684 & 2121 & 13361 & 13844 & 15208 & 9471 \\
\hline \multirow{2}{*}{920} & & $1(8)$ & 8784 & 6683 & - & - & - & - \\
\hline & & $2(4.4)$ & 5989 & 1671 & 5097 & 4939 & 6197 & 3875 \\
\hline \multirow{2}{*}{840} & & $1(8)$ & 10207 & 8017 & - & - & - & - \\
\hline & & $2(4.4)$ & 6919 & 2004 & 5935 & 5741 & 7179 & 4587 \\
\hline
\end{tabular}

Table 2. Results of experiments and calculation methods

2. táblázat A kísérletileg mért értékek és a számitási módszerek eredményei

\begin{tabular}{|c|c|c|c|c|c|c|c|c|}
\hline \multirow[t]{2}{*}{$\begin{array}{l}\text { Height } \\
{[\mathrm{mm}]}\end{array}$} & \multirow[t]{2}{*}{$\begin{array}{l}\text { Type of } \\
\text { glass }\end{array}$} & \multirow{2}{*}{$\begin{array}{c}\text { Number } \\
\text { of glass } \\
\text { layers [mm] }\end{array}$} & \multirow{2}{*}{$\begin{array}{l}\text { Nor [N] } \\
\text { Experimental } \\
\text { results }\end{array}$} & \multicolumn{5}{|c|}{$\begin{array}{l}\text { Ratio of critical force of } \\
\text { calculated and experimental values [\%] }\end{array}$} \\
\hline & & & & Euler & $\begin{array}{c}\text { Allen } \\
{[4]}\end{array}$ & $\begin{array}{c}\text { Zenkert } \\
\text { [5] }\end{array}$ & $\begin{array}{l}\text { Sattler } \\
{[6]}\end{array}$ & $\begin{array}{c}\text { Blaauwendraad } \\
{[7]}\end{array}$ \\
\hline \multirow{11}{*}{1000} & \multirow{5}{*}{ Float } & $1(8)$ & 5672 & 100 & - & - & - & - \\
\hline & & $1(12)$ & 19803 & 96 & - & - & - & - \\
\hline & & $2(4.4)$ & 3490 & 41 & 127 & 123 & 155 & 95 \\
\hline & & $2(6.6)$ & 14575 & 33 & 83 & 84 & 116 & 79 \\
\hline & & $3(4.4 .4)$ & 13425 & 16 & 100 & 103 & 113 & 71 \\
\hline & \multirow{6}{*}{ HSG } & 1(8) & 7506 & 75 & - & - & - & - \\
\hline & & $1(12)$ & 26420 & 72 & - & - & - & - \\
\hline & & $2(4.4)$ & 5278 & 27 & 84 & 81 & 102 & 63 \\
\hline & & $2(6.6)$ & 16699 & 29 & 79 & 77 & 97 & 63 \\
\hline & & $2(8.4)$ & 17495 & 36 & 69 & 70 & 96 & 66 \\
\hline & & $3(4.4 .4)$ & 12684 & 17 & 105 & 109 & 120 & 75 \\
\hline \multirow{2}{*}{920} & & $1(8)$ & 8784 & 76 & - & - & - & - \\
\hline & & $2(4.4)$ & 5989 & 28 & 85 & 82 & 103 & 65 \\
\hline \multirow{2}{*}{840} & & $1(8)$ & 10207 & 79 & - & - & - & - \\
\hline & & $2(4.4)$ & 6919 & 29 & 86 & 83 & 104 & 66 \\
\hline
\end{tabular}

Table 3. Quantitative comparison of results of experiments and calculation methods

3. táblázat A kísérletileg mért értékek és a számitási módszerek eredményeinek kvantitatívösszehasonlítása 


\section{Conclusions}

a) The following conclusions can be drawn based on the theoretical calculations:

- The critical buckling force increases in the case of reduced rotations of the glass fin in the supporting structure.

- The coefficient of fixing ( $n$ ) changes during testing, due to the changing supporting conditions caused by the continuous compression of the elastic damping material during loading.

- The calculation methods of the critical buckling force do not distinguish between float and heat-strengthened (HSG) glass.

- Euler's formula should be applied only in the case of float, monolithic single layer glass.

- The critical buckling force with Sattler's formula overestimates the experimental values in the case of laminated glass consisted of float glass and gives correct values in the case of laminated glass consisted of HSG glass.

- The critical buckling force with Allen's and Zenkert's formulae result the same, usually lower, conservative values compared to the experimental results.

- In the case of conservative engineering calculations the use of Blaauwendraad's formula is suggested.

b) The following conclusions can be drawn based on the laboratory experiments [1]:

- Three different stages can be distinguished in the buckling behaviour of glass columns.

- The buckling behaviour is not affected by the loading rate in the case of loading rate of $0.5 \mathrm{~mm} / \mathrm{min}$ and $1 \mathrm{~mm} / \mathrm{min}$.

- The critical buckling load is reduced with the increase of the number of glass layers.

- The allowed buckling load during structural design calculations is suggested to be the maximum load of the $1^{\text {st }}$ Stage (stable state) reduced with safety factors.

- The $2^{\text {nd }}$ Stage in the buckling behaviour is mainly influenced by the type of the supporting structure (fixed/pinned) and the stiffness of the glass columns.

- In the case of laminated glass, the horizontal deformations and the load bearing capacity are influenced by the shear modulus of the interlayer material, therefore the force in the $3^{\text {rd }}$ Stage decreases.

- In the case of a single layer HSG glass with height of $1000 \mathrm{~mm}$ the critical buckling force increased with $\sim 30 \%$ compared to that of float glass.

\section{Acknowledgement}

Authors express their gratitude to Rákosy Glass Ltd. for providing the specimens. Authors are thankful to the Department of Construction Materials and Engineering Geology, BME and Mr. András Eipl (Struktúra Kft) and Mr. Péter Molnár (Struktúra Kft) for their technical support.

References

[1] Nehme, K. - Jakab, A. - Nehme, S.G.: Experiments on the buckling behaviour of glass columns. Part 1. Épitöanyag, 65. évf. 3. szám (2013), pp. 62-66. http://dx.doi.org/10.14382/epitoanyag-jsbcm.2013.13

[2] Pankhardt, K.: Load bearing glasses. Testing of construction glasses, Saarbrücken: Lap Lambert, 2012. -ISBN: 9783847321910

[3] Nehme, K. - Nehme, S. G. - Jakab, A.: Üveg oszlopok kihajlása, (Buckling of glass columns) Műszaki Tudomány az Észak-Kelet Magyarországi Régióban 2013, Konferencia előadásai, szerkesztette: Pokorádi L., DE MK, 2013. június 4., DAB Müszaki Szakbizottsága, Debrecen, 2013, ISBN 978-963-7064-30-2, pp. 378-388.

[4] Allen, H.G.: Analysis and Design of Structural Sandwich Panels, Pergamon, Oxford. UK, CH.8. 1969.

[5] Sattler, K. - Stein, P.: Ingenieurbauten 3, Theorie und Praxis, SpringerVerlag, Wien 1974.

[6] Zenkert, D. (editor): The Handbook of Sandwich Construction, Engineering Materials Advisory Service Ltd, Cradley Heath, West-Midlands, United Kingdom 1997.

[7] Blaauwendraad, J.: Buckling of laminated glass coloumns, Heron, Vol. 52, No. 1/2, 2007, pp.147-164.

[8] Wölfel, E.: Nachgiebiger Verbund eine Näherungslösung und deren Anwendungs-möglichkeiten, Stahlbau, No.6, 1987, pp.173-180.

$\underline{\text { Ref.: }}$

Kinga Nehme - András Jakab - Salem Georges Nehme: Experiments on the buckling behaviour of glass columns. Part 2. Építőanyag, 65. évf. 4. szám (2013), 112-117. p. http://dx.doi.org/10.14382/epitoanyag-jsbcm.2013.21

Üvegoszlopok kihajlásának laboratóriumi vizsgálata. 2. rész.

Korábbi cikkünkben [1] laboratóriumi kísérleteink alapján ismertettük a teherhordó üveg oszlopok kihajlási viselkedését, valamint vizsgáltuk az üveg oszlopok teherbírási kérdéskörét. Jelen cikkünkben szintén a teherhordó üveg oszlopokkal foglalkozunk, a meglévố számítási eljárásokkal meghatározzuk a kritikus terhet, elemezzük a stabilitási viselkedést. Összehasonlítjuk a kísérleti és elméleti számítások eredményeit. Eredményeink tükrében elemezzük a nemzetközi irodalomban fellelhetô számítási eljárásokat. A BME Épitôanyagok és Mérnökgeológiai Tanszék laboratóriumában kísérleti úton vizsgáltuk az üveg oszlopok kihajlását. Több mint $60 \mathrm{db}$ próbatestet tönkremenetelig terheltünk. Kísérleti eredményeink alapján meghatároztuk a kritikus erôt, erôalakváltozás diagramokkal szemléltettük a tönkremeneteli és stabilitási folyamatokat. A kritikus teher és karcsúság összefüggését meghatároztuk, monolitikus (egy rétegú) és többrétegú üvegekből felépülô üveg oszlopok esetére.

Kulcsszavak: üveg oszlop, kihajlás, teherbíró üveg, stabilitás, átlátszóság

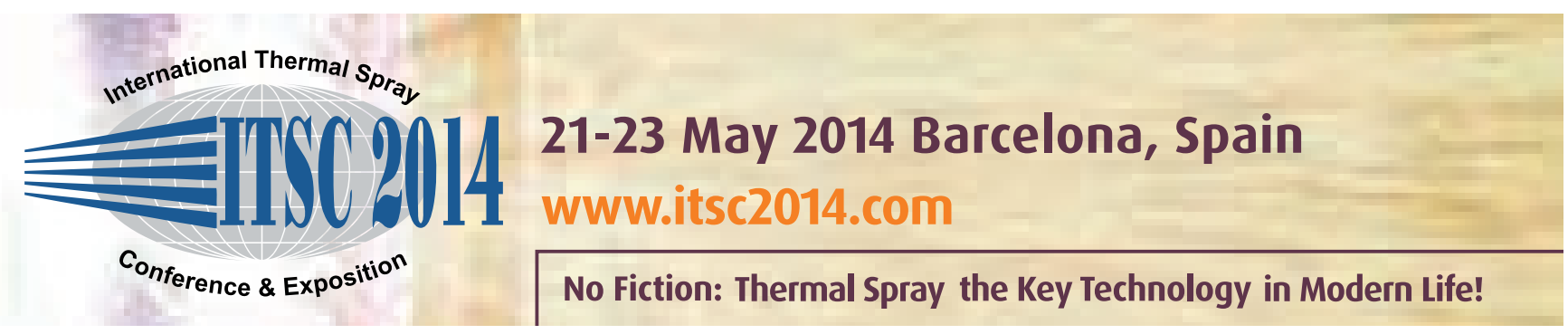

